\title{
Gleeble Compression Tests on As-cast Alloy 709 Samples
}

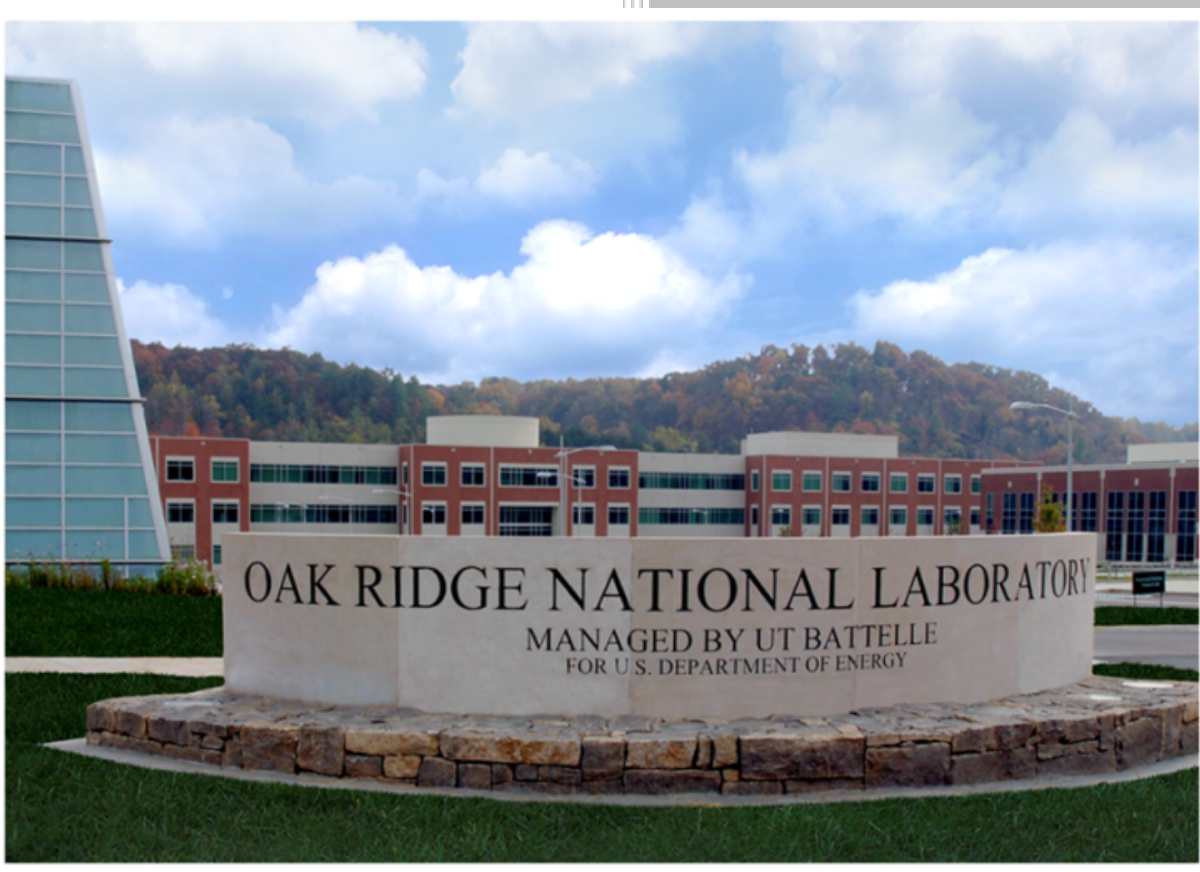

Yanli Wang

Suhong Zhang

Zhili Feng

August 10, 2018

Approved for public release.

Distribution is unlimited. 


\section{DOCUMENT AVAILABILITY}

Reports produced after January 1, 1996, are generally available free via US Department of Energy (DOE) SciTech Connect.

Website http://www.osti.gov/scitech/

Reports produced before January 1, 1996, may be purchased by members of the public from the following source:

National Technical Information Service

5285 Port Royal Road

Springfield, VA 22161

Telephone 703-605-6000 (1-800-553-6847)

TDD 703-487-4639

Fax 703-605-6900

E-mail info@ntis.gov

Website http://www.ntis.gov/help/ordermethods.aspx

Reports are available to DOE employees, DOE contractors, Energy Technology Data Exchange representatives, and International Nuclear Information System representatives from the following source:

Office of Scientific and Technical Information

PO Box 62

Oak Ridge, TN 37831

Telephone 865-576-8401

Fax 865-576-5728

E-mail reports@osti.gov

Website http://www.osti.gov/contact.html

This report was prepared as an account of work sponsored by an agency of the United States Government. Neither the United States Government nor any agency thereof, nor any of their employees, makes any warranty, express or implied, or assumes any legal liability or responsibility for the accuracy, completeness, or usefulness of any information, apparatus, product, or process disclosed, or represents that its use would not infringe privately owned rights. Reference herein to any specific commercial product, process, or service by trade name, trademark, manufacturer, or otherwise, does not necessarily constitute or imply its endorsement, recommendation, or favoring by the United States Government or any agency thereof. The views and opinions of authors expressed herein do not necessarily state or reflect those of the United States Government or any agency thereof. 
ORNL/TM- 2018/932

Materials Science and Technology Division

\section{GLEEBLE COMPRESSION TESTS ON AS-CAST ALLOY 709 SAMPLES}

Yanli Wang, Suhong Zhang, Zhili Feng

August 10, 2018

Prepared by OAK RIDGE NATIONAL LABORATORY

Oak Ridge, TN 37831-6283

managed by

UT-BATTELLE, LLC

for the

US DEPARTMENT OF ENERGY

under contract DE-AC05-00OR22725 



\section{CONTENTS}

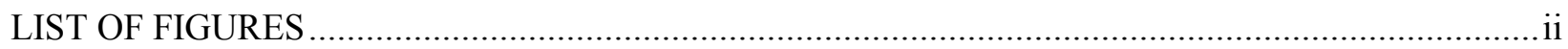

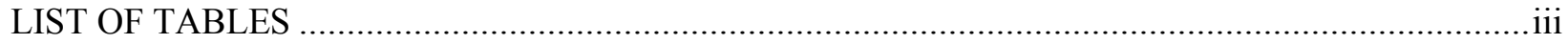

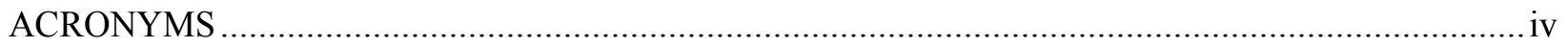

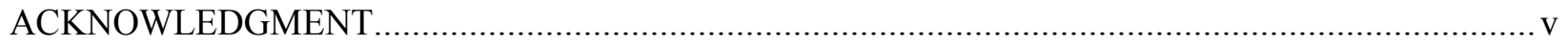

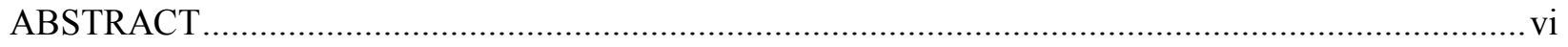

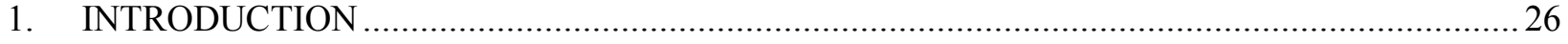

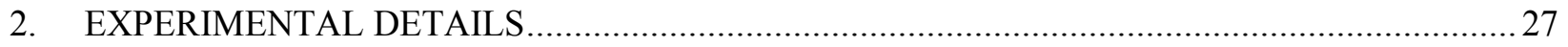

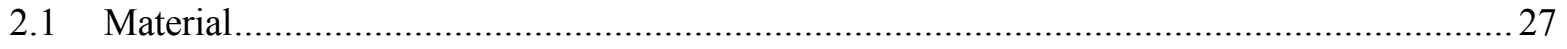

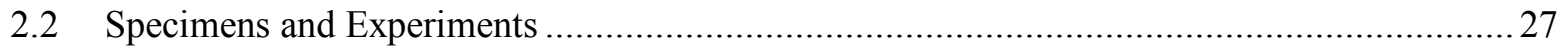

2.2.1 Specimen geometries ..................................................................... 27

2.2.2 Gleeble compression testing .............................................................. 29

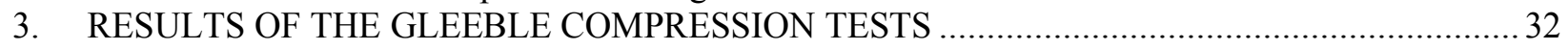

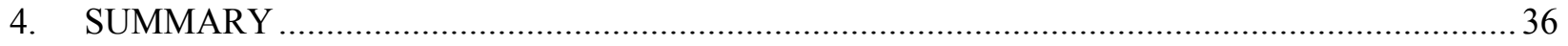

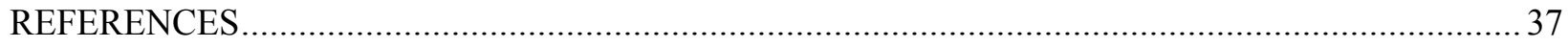




\section{LIST OF FIGURES}

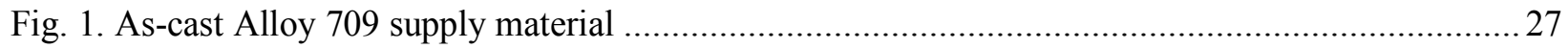

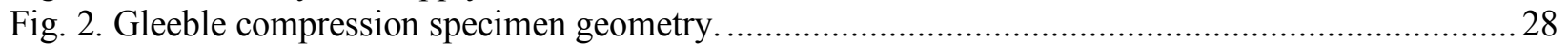

Fig. 3. Layout of the Gleeble compression specimens with respect to the as-received as-cast Alloy

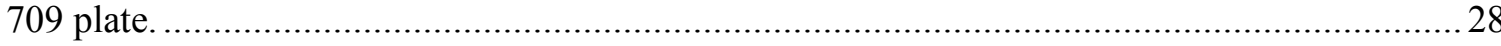

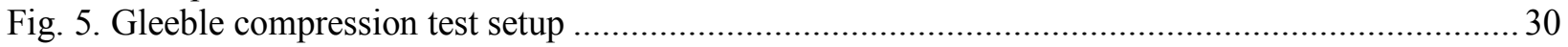

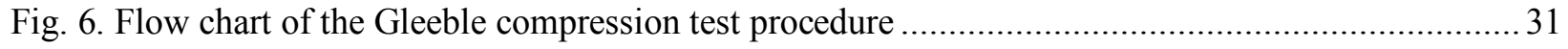

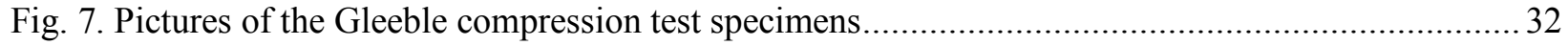

Fig. 8. Pictures of the Alloy 709 specimen during Gleeble compression test at $1100{ }^{\circ} \mathrm{C} \ldots \ldots \ldots \ldots \ldots \ldots \ldots \ldots . . . . . . . . .33$

Fig. 9. True stress vs. true strain curves of Gleeble compression tests on as-cast Alloy 709 at

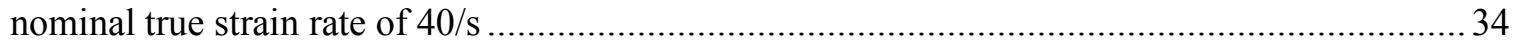




\section{LIST OF TABLES}

Table 1. Chemical compositions of the as-cast Alloy 709 (heat 58776-3), wt\% ................................2 27

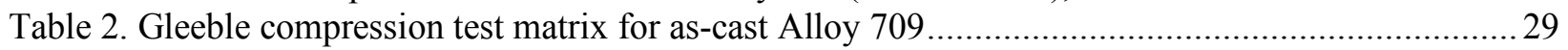

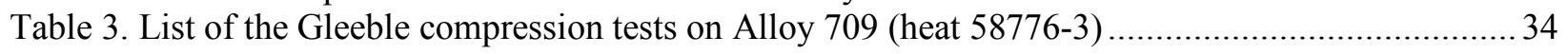




\section{ACRONYMS}

ART Advanced Reactor Technologies

ANL Argonne National Laboratory

DOE Department of Energy

ORNL Oak Ridge National Laboratory

SFR Sodium Fast Reactor 


\section{ACKNOWLEDGMENT}

The research was sponsored by the U.S. Department of Energy, under contract No. DE-AC05-

00OR22725 with Oak Ridge National Laboratory (ORNL), managed and operated by UT-Battelle, LLC. Programmatic direction was provided by the Office of Nuclear Energy.

The authors gratefully acknowledge the support provided by Alice Caponiti, Director, Office of Advanced Reactor Technologies (ART), Sue Lesica, Federal Manager, ART Advanced Materials Program, Robert Hill of ANL, National Technical Director, ART Fast Reactors Campaign, and Sam Sham of ANL, ART Technology Area Lead on Advanced Materials.

The authors acknowledge technical support from David Alan Frederick and Zhenggang Wu of ORNL. The authors thank T. L. Sham, Mark C. Messner and Xuan Zhang of ANL for discussions on the experiment. The time spent by Jian Chen and Lianshan Lin of ORNL in reviewing this report is greatly appreciated. 


\begin{abstract}
Compression tests were performed on as-cast Alloy 709 (heat 58776-3) using Gleeble® 3500-GTC system at Oak Ridge National Laboratory (ORNL). The testing temperature range was $900{ }^{\circ} \mathrm{C}$ to $1200{ }^{\circ} \mathrm{C}$ and the nominal true strain rate range was $0.001 / \mathrm{s}$ to $40 / \mathrm{s}$. The tested specimens were delivered to Argonne National Laboratory (ANL) for confirmatory microstructure analysis. The test data were provided to ANL for the construction of the processing map for Alloy 709.

This report summarizes the compression tests performed on the as-cast Alloy 709 and fulfills the FY18 milestone M3NT-18OR050502026-"Complete the Gleeble compression tests of as-cast Alloy 709 samples" under the ORNL work package NT-18OR05050202-“A709 Development - ORNL”.
\end{abstract}




\section{INTRODUCTION}

Nuclear power contributes significantly to meeting the nation's energy, economic, environmental, and national security needs. Sodium Fast Reactor (SFR) is a leading candidate for recycling used fuel to close the fuel cycle and for power generation. While the SFR technology is relatively mature, there must be improvements in the capital cost and economic return before the private sector will invest in the largescale, commercial deployment of SFRs. Further, greater safety margins and increased flexibility will also be required of any new advanced reactor systems. Flexibility, safety, and economics were all identified as the key needs for advanced reactors.

Advanced materials can have a significant impact on capital costs reduction even if the commodity prices of new materials are higher than traditional steels. This is due to innovative designs and design simplifications that could be made possible using materials with enhanced mechanical properties. Improved materials performance also impacts safety through improved reliability and greater design margins. Improved material reliability could also result in reduced down time.

Due to the significant enhancement in mechanical properties of the austenitic stainless steel Alloy 709 relative to $316 \mathrm{H}$ stainless steel (Busby et al., 2008), a reference construction material for SFR systems, code qualification of Alloy 709 was recommended in FY14. Qualification of additional higher performance structural material, the Alloy 709 advanced stainless steel, to expand Fast Reactors (FR) design envelops is one of the key areas that the FR Campaign currently focuses on. A comprehensive plan for the development of a 500,000-hour, $760{ }^{\circ} \mathrm{C}$ ASME Code Case and the resolution of structural integrity issues identified by NRC for Alloy 709 was developed in FY15. A Phase I implementation of this plan that includes a 100,000-hour, 650C ASME code case and the initiation of very long term creep tests, and thermal aging and sodium exposure of Alloy 709 has been established. In collaboration with material vendor, G.O. Carlson Inc. of Pennsylvania, the ART program successfully scaled the production of Alloy 709 from a laboratory heat of 500 pounds to a commercial heat of 55,000 pounds (Natesan, et al.,2017). Hot-rolled plates were fabricated from the first commercial heats to support testing.

Efforts to execute the Phase I plan continued in FY18. The focus of the FY18 Alloy 709 effort involves the development of the processing map to support Alloy 709 fabrication optimization. This report summarizes the compression tests performed on the as-cast Alloy 709 (heat 58776) in support of the development of the processing map. 


\section{EXPERIMENTAL DETAILS}

\subsection{MATERIAL}

The Alloy 709 material (heat 58776-3) used in this report was supplied by ANL. The material was in ascast condition and supplied in plate shape. The plate was approximately $420 \mathrm{~mm}$ in length and $240 \mathrm{~mm}$ in width. It has a tapered thickness of about $22 \mathrm{~mm}$ to $50 \mathrm{~mm}$. Pictures of the as-received plate are shown in Fig. 1.
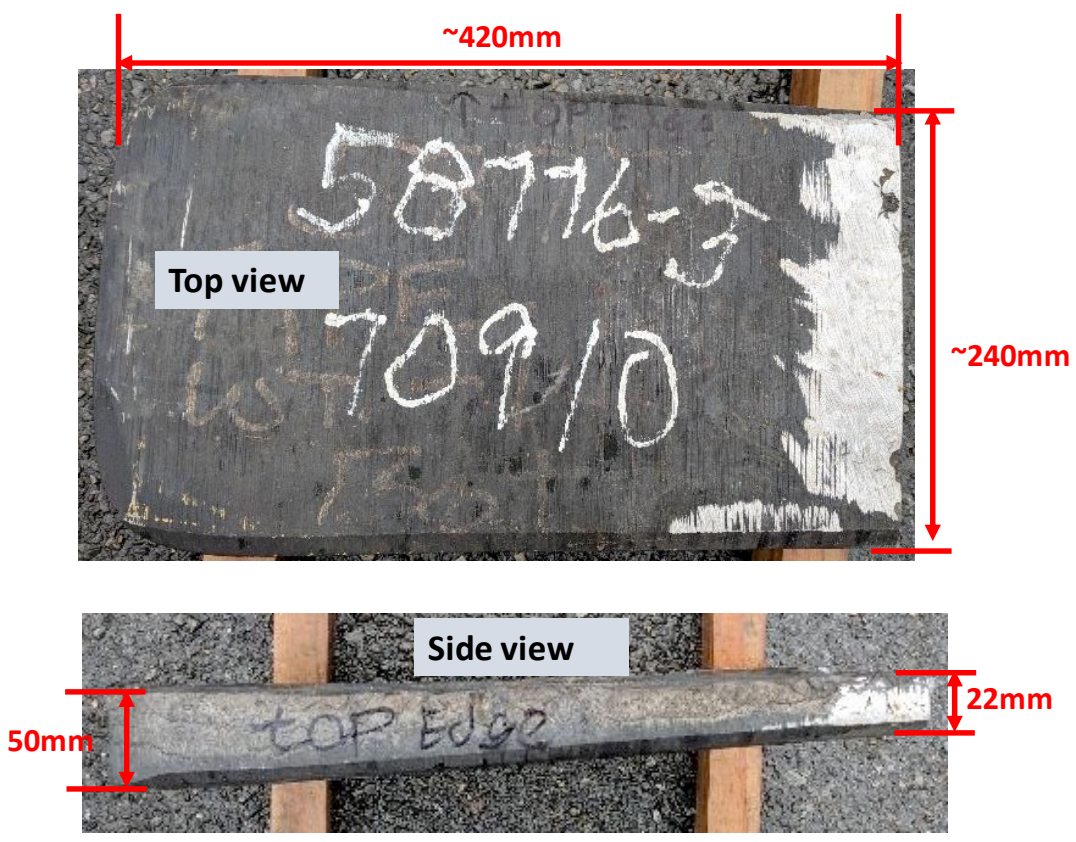

Fig. 1. As-cast Alloy 709 supply material

The compositions of this plate are listed in Table 1.

Table 1. Chemical compositions of the as-cast Alloy 709 (heat 58776-3), wt\%

\begin{tabular}{l|l|l|l|l|l|l|l|l|l|l|l}
\hline $\mathrm{C}$ & $\mathrm{Cr}$ & $\mathrm{Ni}$ & $\mathrm{Mn}$ & $\mathrm{Mo}$ & $\mathrm{N}$ & $\mathrm{Si}$ & $\mathrm{P}$ & $\mathrm{Ti}$ & $\mathrm{Nb}$ & $\mathrm{N}$ & $\mathrm{Fe}$ \\
\hline 0.066 & 19.93 & 24.98 & 0.91 & 1.51 & 0.148 & 0.44 & 0.014 & 0.04 & 0.26 & 0.0045 & Bal. \\
\hline
\end{tabular}

\subsection{SPECIMENS AND EXPERIMENTS}

\subsubsection{Specimen geometries}

The Gleeble compression specimen was cylindrical shape with diameter of $10 \mathrm{~mm}$ and length of $15 \mathrm{~mm}$. The specimen drawing is shown in Fig. 2.

A $12.5 \mathrm{~mm}$ all-around edge was cut off from the as-received plate and discarded to avoid any possible edge effect from the preparation of this plate. The Gleeble compression specimens were machined from $12.5 \mathrm{~mm}$ wide blocks with the cylinder centerline along the plate width direction. The specimens were machined from the center of plate thickness to eliminate the surface effect. The specimen layout is schematically shown in Fig. 3. 

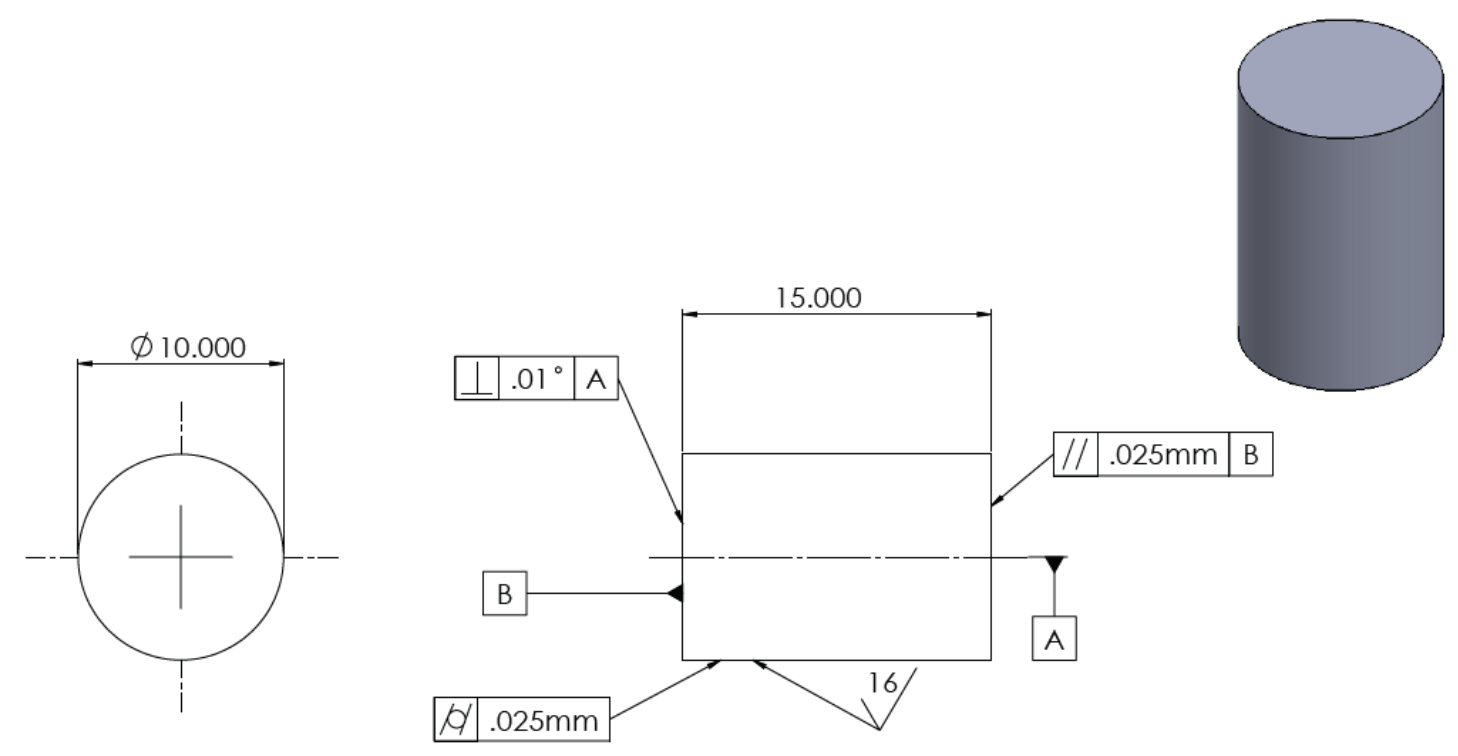

Fig. 2. Gleeble compression specimen geometry.

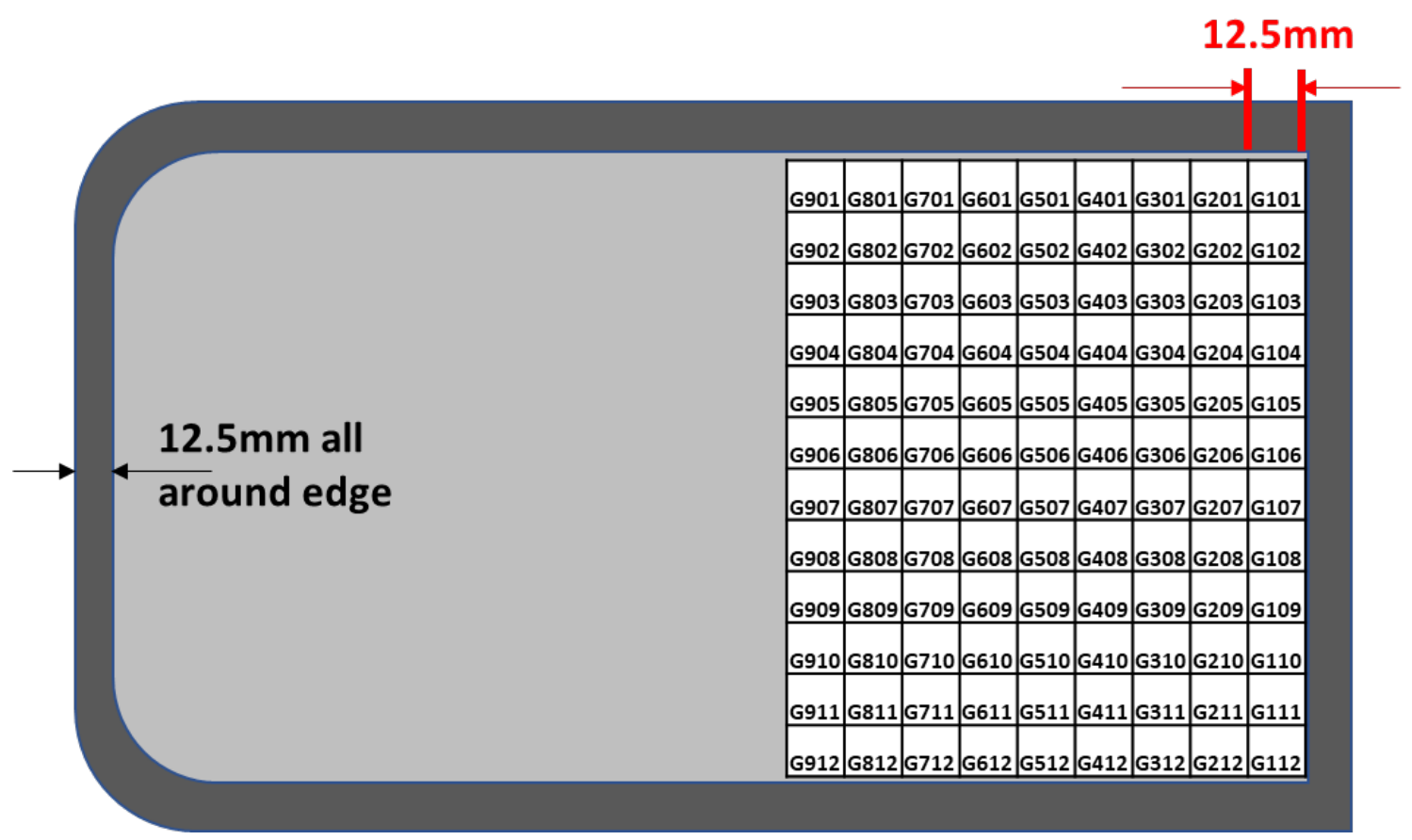

Fig. 3. Layout of the Gleeble compression specimens with respect to the as-received as-cast Alloy 709 plate. 


\subsubsection{Gleeble compression testing}

The compression tests were performed on the Gleeble® 3500-GTC system at ORNL. A picture of the Gleeble® 3500-GTC system is shown in Fig. 4. Prior to the compression testing, the test chamber was evacuated and back filled with pure Argon gas to minimize oxidation of the specimens.

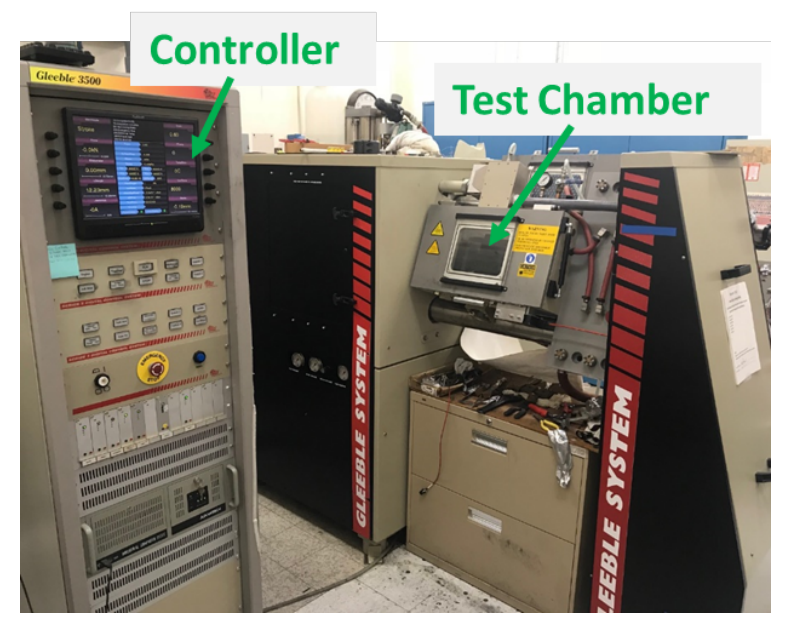

Fig. 4. The Gleeble® 3500-GTC system at ORNL

The testing matrix in support of the construction of the processing map is summarized in Table 2 . The testing temperature was from $900{ }^{\circ} \mathrm{C}$ to $1200{ }^{\circ} \mathrm{C}$, and the nominal true strain rate was from $0.001 / \mathrm{s}$ to $40 / \mathrm{s}$. The matrix consists a total of 35 compression tests.

Table 2. Gleeble compression test matrix for as-cast Alloy 709

\begin{tabular}{c|c|c|c|c|c}
\hline $\begin{array}{c}\text { Temperature, } \\
\text { C }\end{array}$ & \multicolumn{5}{|c}{ Nominal true strain rate, } \\
\hline 900 & 0.001 & 0.01 & 0.1 & 1 & 40 \\
\hline 950 & 0.001 & 0.01 & 0.1 & 1 & 40 \\
\hline 1000 & & & & & \\
\hline 1050 & 0.001 & 0.01 & 0.1 & 1 & 40 \\
\hline 1100 & 0.001 & 0.01 & 0.1 & 1 & 40 \\
\hline 1150 & 0.001 & 0.01 & 0.1 & 1 & 40 \\
\hline 1200 & 0.001 & 0.01 & 0.1 & 1 & 40 \\
\hline & 0.001 & 0.01 & 0.1 & 1 & 40 \\
\hline
\end{tabular}

The testing procedure followed ASTM E209. The compression tests were controlled with a computerized program. The compression tests were performed under Argon protection gas environment. A picture of the experimental setup for a scope testing on a compression specimen is shown Fig. 5. The specimen was being loading in a horizontal position. The heating rate was controlled to be $2.5^{\circ} \mathrm{C} / \mathrm{s}$ under a small compression load control and the heating mechanism was resistance heating. Graphite foils and tantalum foil spacers were used at the interfaces between the specimen and the tungsten carbide loading anvils to 
equilibrate the temperature along the specimen length direction. Three thermal couples were spot-welded on to the specimen surface with one at the mid-length for temperature control and two at $2 \mathrm{~mm}$ away each end to monitor the temperature. The specimens were equilibrated at the target temperature for 2 minutes before the compression process began. During this 2-minute hold period, the temperature difference along the specimen length direction was within the ASTM E209 specification. During compression test, the temperature reading of the two thermocouples close to the end of the specimen was monitored but was not considered as a crucial control parameter because they might contact the loading fixture under large deformation, which would result in false reading.

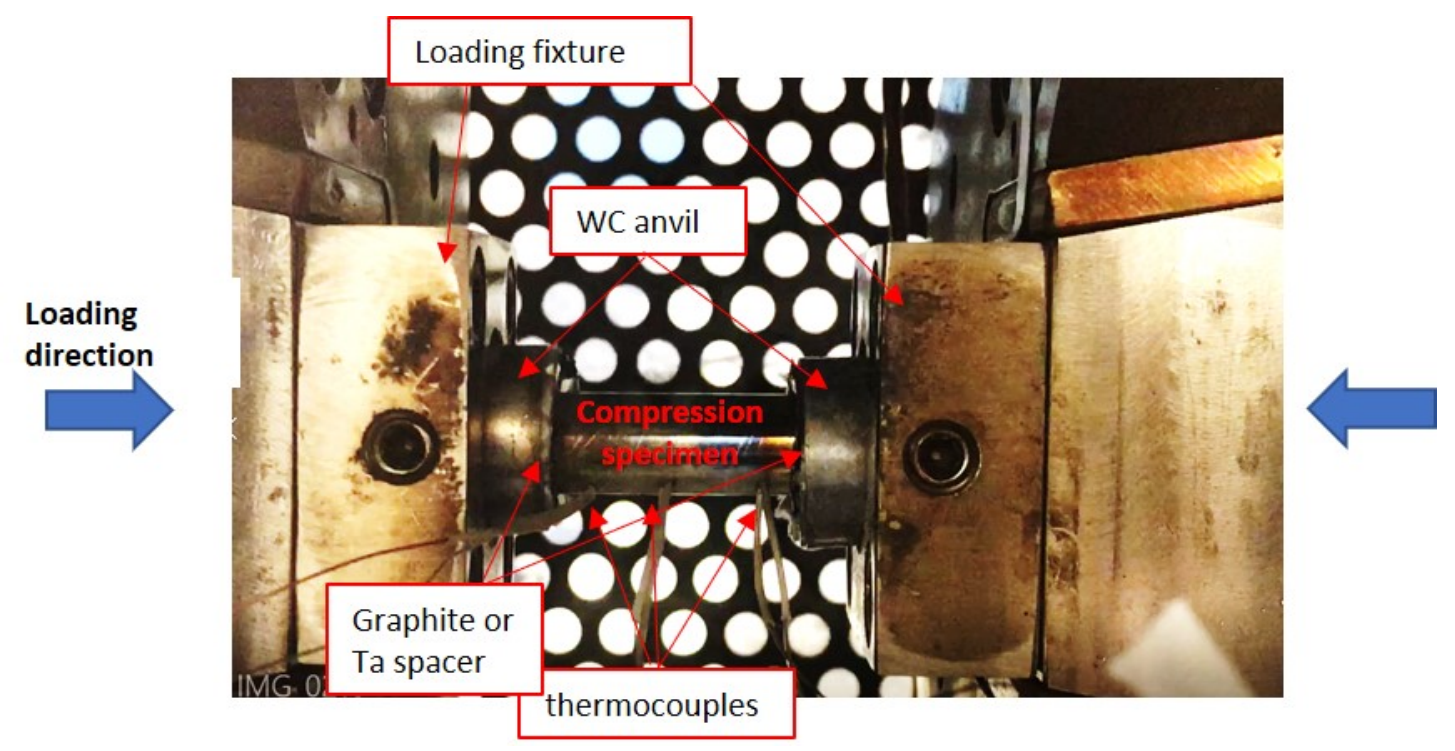

Fig. 5. Gleeble compression test setup

All compression tests with nominal true strain rates of $1 / \mathrm{s}$ and lower used constant true strain rate control. The true strain is defined as

$$
\varepsilon=\ln \left(\frac{l}{l_{0}}\right)
$$

where $\varepsilon$ is the true strain, $l$ is the specimen length and $l_{o}$ the original specimen length prior to the compression testing. The control software for Gleeble® 3500-GTC system allows control mode be defined as constant true strain rate control.

However, several scoping tests were performed at the highest testing speed under true strain rate control, the results show that the Gleeble® 3500-GTC system responded with much slower speed than the command, and it was then decided to switch to stroke control and over drive the system with a command speed of $600 \mathrm{~mm} / \mathrm{s}$ to achieve the nominal true strain rate of $40 / \mathrm{s}$.

For construction of the processing map, the stress is expressed as true stress with the following equation,

$$
\sigma=\frac{P}{A}
$$

Where $\sigma, p$ and $A$ are the true stress, the load and the cross-sectional area. 
Assuming the material volume is constant, i.e,

$$
A * l=A_{o} * l_{o}
$$

Equation (2) can therefore be converted to

$$
\sigma=\sigma_{e} *(1+e)
$$

Where $\sigma_{e}$ is the engineering stress and defined as $\left(P / A_{o}\right)$, and $e$ is the engineering strain and defined as $\left(l_{o^{-}}\right.$ l) $/ l_{o}$. The compression strain is converted to be positive in this case.

Immediately after the compression test, the specimens were water quenched to preserve the microstructure features for further microscopic analysis.

A flow chart of the above described compression test procedure is demonstrated in Fig. 6.

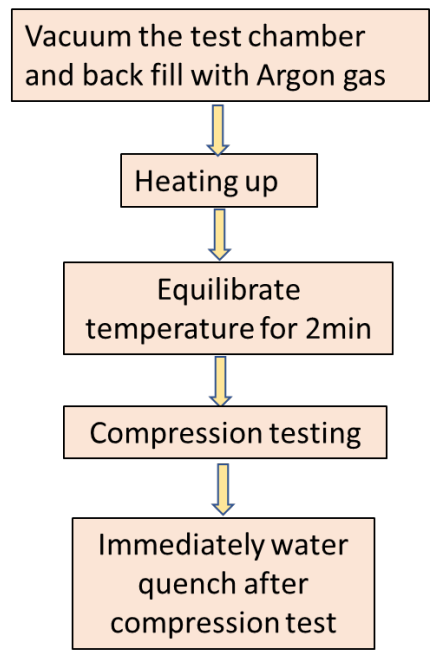

Fig. 6. Flow chart of the Gleeble compression test procedure 


\section{RESULTS OF THE GLEEBLE COMPRESSION TESTS}

Pictures of a specimen before testing and another specimen after compression testing are shown in Fig. 7. The specimens were found to show an irregular shape after compression tests due to the non-homogenous microstructure of the as-cast material, unlike the conventionally barreled shape for specimens with uniform microstructure. The side surfaces of the test specimens were not smooth.

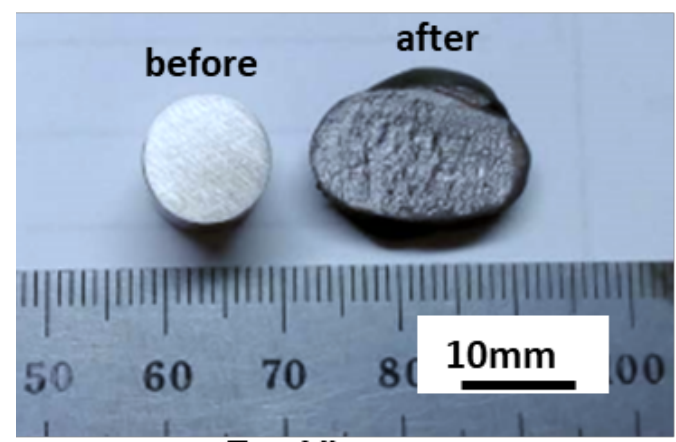

Top View

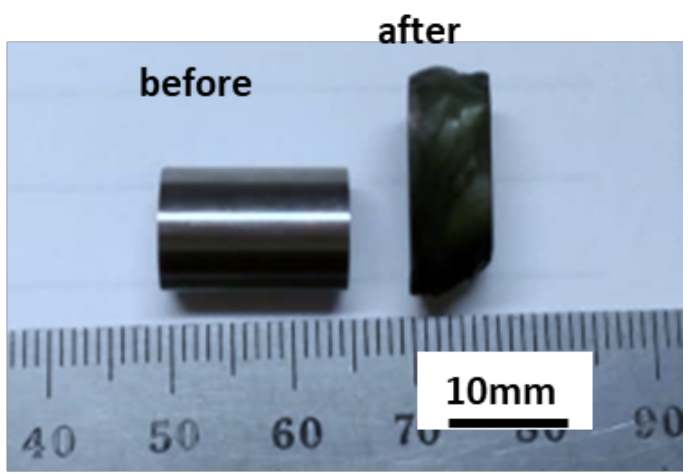

Side View

Fig. 7. Pictures of the Gleeble compression test specimens

A series of images of a specimen was recorded during the Gleeble compression testing and shown in the Fig. 8. The specimen was continuously compressed to the final thickness of about $6 \mathrm{~mm}$ at a prescribed constant true strain rate. 

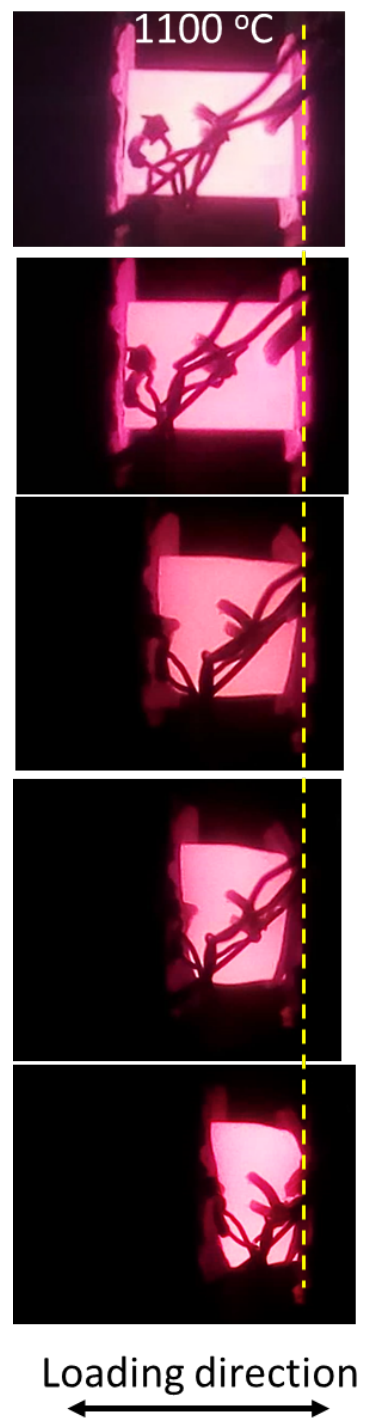

Fig. 8. Pictures of the Alloy 709 specimen during Gleeble compression test at $1100{ }^{\circ} \mathrm{C}$

Examples of the true stress vs. true strain curves at different testing temperatures are plotted in Fig. 9. The nominal true strain rate was $40 / \mathrm{s}$ for these tests. The waviness of the true stress vs. true strain curves is due to ringing in the load signal at the high testing speed. As expected, the true stresses were shown to increase as the testing temperature decreased.

All the valid compression tests performed are listed in Table 3. A total of 45 tests were performed, with several extra tests at nominal true strain rate of $5 / \mathrm{s}$ and with several repeats for some conditions to confirm the results. After compression tests, the graphite or tantalum spacers were stuck to the specimen, therefore the final thickness reported in this table is only for reference because the value does not reflect the true specimen thickness. All the tested specimens along with the test data (including time, load, displacement) were delivered to ANL for microstructure analysis and for construction of the processing map. 


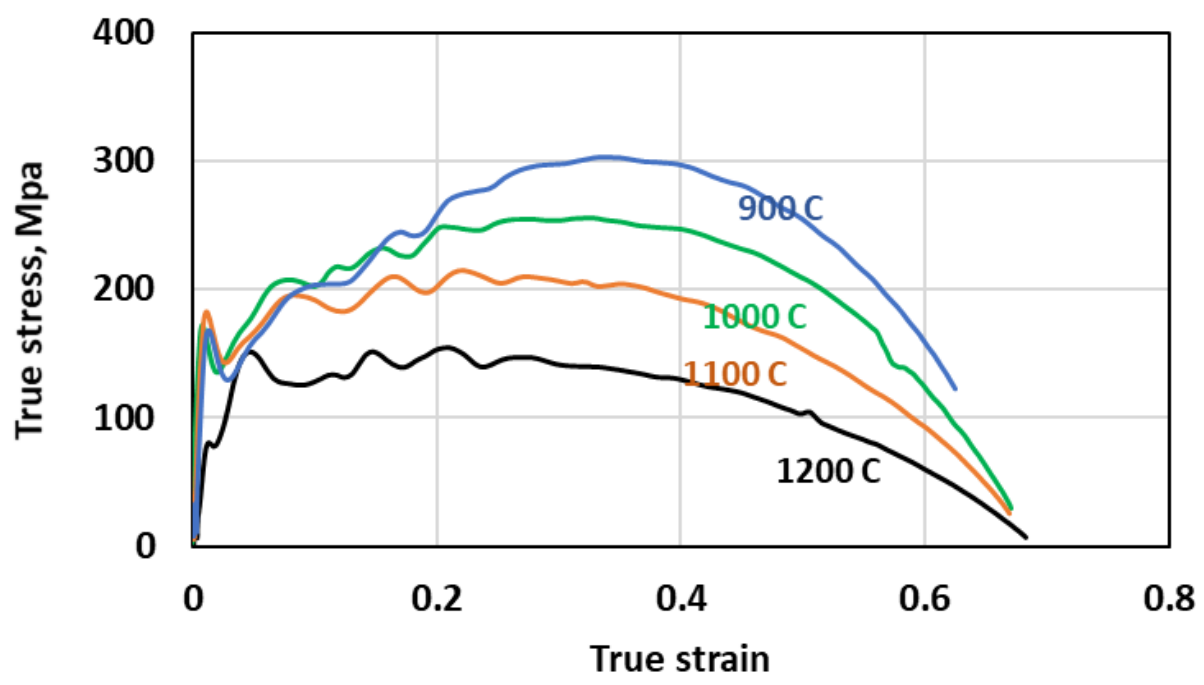

Fig. 9. True stress vs. true strain curves of Gleeble compression tests on as-cast Alloy 709 at nominal true strain rate of $40 / \mathrm{s}$

Table 3. List of the Gleeble compression tests on Alloy 709 (heat 58776-3)

\begin{tabular}{c|c|c|c|c|c}
\hline Test No. & $\begin{array}{c}\text { Specimen } \\
\text { ID }\end{array}$ & $\begin{array}{c}\text { Test Temp. } \\
\text { C }\end{array}$ & $\begin{array}{c}\text { nominal true } \\
\text { strain rate, } \mathbf{1 / s}\end{array}$ & $\begin{array}{c}\text { Final thickness at RT, } \\
\mathbf{m m}\end{array}$ & Notes \\
\hline 1 & G910 & 1000 & 5 & 5.83 & extra test condition \\
\hline 2 & G206 & 900 & 5 & 6.35 & extra test condition \\
\hline 3 & G808 & 1200 & 5 & 5.84 & extra test condition \\
\hline 4 & G109 & 1100 & 5 & 6 & extra test condition \\
\hline 5 & G904 & 1100 & 5 & 5.9 & \\
\hline 6 & G707 & 1200 & 1 & 5.92 & \\
\hline 7 & G201 & 1200 & 0.1 & 5.9 & \\
\hline 8 & G403 & 1100 & 0.1 & 5.9 & partial data are valid \\
\hline 9 & G611 & 900 & 0.001 & 6.04 & \\
\hline 10 & G106 & 900 & 0.1 & 6.25 & \\
\hline 11 & G909 & 1000 & 0.1 & 4.5 & \\
\hline 12 & G310 & 1100 & 0.01 & 6.6 & \\
\hline 13 & G809 & 900 & 0.001 & 5.81 & \\
\hline 14 & G108 & 1000 & 0.001 & 6.18 & \\
\hline 15 & G203 & 1100 & 0.001 & 6.77 & \\
\hline 16 & G710 & 1200 & 0.001 & 6.81 & \\
\hline 17 & G202 & 1200 & 40 & 5.84 & \\
\hline
\end{tabular}


Table 3 continued

\begin{tabular}{|c|c|c|c|c|c|}
\hline Test No. & $\begin{array}{l}\text { Specimen } \\
\text { ID }\end{array}$ & $\begin{array}{c}\text { Test } \\
\text { Temp. C }\end{array}$ & $\begin{array}{c}\text { nominal true } \\
\text { strain rate, } \\
1 / \mathrm{s}\end{array}$ & $\begin{array}{c}\text { Final thickness } \\
\text { at } \mathrm{RT}, \mathrm{mm}\end{array}$ & Notes \\
\hline 18 & G409 & 1000 & 40 & 6.03 & \\
\hline 19 & G702 & 1100 & 40 & 5.93 & \\
\hline 20 & G107 & 900 & 40 & 6.78 & \\
\hline 21 & G111 & 900 & 1 & 6.95 & \\
\hline 22 & G905 & 950 & 1 & 6.85 & \\
\hline 23 & G602 & 1000 & 1 & 7 & partial data are valid \\
\hline 24 & G211 & 1050 & 1 & 7.2 & \\
\hline 25 & G401 & 1100 & 1 & 5.95 & \\
\hline 26 & G709 & 1150 & 1 & 5.73 & \\
\hline 27 & G101 & 900 & 0.01 & 6.2 & \\
\hline 28 & G604 & 1000 & 0.01 & 6.45 & partial data are valid \\
\hline 29 & G901 & 1200 & 0.01 & 6.36 & \\
\hline 30 & G301 & 1125 & 2 & 6.5 & \\
\hline 31 & G911 & 1150 & 40 & 7.02 & \\
\hline 32 & G305 & 950 & 0.1 & 7.05 & \\
\hline 33 & G603 & 1150 & 7 & 6.33 & extra test condition \\
\hline 34 & G711 & 950 & 7 & 7.15 & extra test condition \\
\hline 35 & G208 & 1055 & 40 & 5.92 & \\
\hline 36 & G205 & 960 & 40 & 6.38 & \\
\hline 37 & G512 & 1050 & 0.1 & 6.2 & \\
\hline 38 & G110 & 1150 & 0.1 & 5.58 & \\
\hline 39 & G511 & 1050 & 0.1 & 6.24 & repeat \# 37 \\
\hline 40 & G601 & 950 & 0.01 & 7.2 & \\
\hline 41 & G307 & 1050 & 0.01 & 5.9 & partial data are valid \\
\hline 42 & G608 & 1150 & 0.01 & 6.7 & \\
\hline 43 & G605 & 1150 & 0.001 & 6.1 & \\
\hline 44 & G701 & 1050 & 0.001 & 6.37 & \\
\hline 45 & G302 & 950 & 0.001 & 6.63 & \\
\hline
\end{tabular}




\section{SUMMARY}

Gleeble compression tests were performed on as-cast Alloy 709 (heat 58776-3) to generate necessary information to support the development of the processing map for Alloy 709. A total of 45 compression tests were performed at a temperature range of $900{ }^{\circ} \mathrm{C}$ to $1200{ }^{\circ} \mathrm{C}$ and the true strain rates were between $0.001 / \mathrm{s}$ to $40 / \mathrm{s}$. All the tested specimens along with the test data were delivered to ANL for microstructure analysis and for construction of the processing map. This report fulfills the FY18 milestone M3NT-18OR050502026-"Complete the Gleeble compression tests of as-cast Alloy 709 samples" under the ORNL work package NT-18OR05050202-“A709 Development - ORNL”. 


\section{REFERENCES}

Busby, J. T., S. Byun, R. Klueh, P. Maziasz, and J. Vitek, K. Natesan, M. Li, R. Wright, S. Maloy, M. Toloczko, A. Motta, B. D. Wirth, G. R. Odette, and T. Allen, "Candidate Developmental Alloys for Improved Structural Materials for Advanced Fast Reactors," ORNL/GNEP/LTR-2008-023, March 2008.

Natesan, K., Zhang, X., Sham, T.-L., and H. Wang, "Report on the completion of the procurement of the first heat of Alloy 709", ANL-ART-89, Argonne National Laboratory, June 2017. 
ORNL/TM-2018/932

\section{ELECTRONIC DISTRIBUTION}

Name
Lesica, S.
Sowinski, T. E..
Grandy, C.
Hill, R.N.
Jetter, R.I.
Chen, Jian
Li, M.
Lin, L.
McMurtrey, M.
Messner, M.C.
Sham, T.-L.
Zhang, Xuan
Wang, H.
Wang, Y.
Wright, R.N.

Affiliation
DOE-NE
DOE
ANL
ANL
R.I. Jetter Consulting
ORNL
ANL
ORNL
INL
ANL
ANL
ANL
ORNL
ORNL
INL

\author{
Email \\ sue.lesica@nuclear.energy.gov \\ thomas.sowinski@nuclear.energy.gov \\ cgrandy@anl.gov \\ bobhill@anl.gov \\ bjetter@sbcglobal.net \\ chenj2@ornl.gov \\ mli@anl.gov \\ lin1@ornl.gov \\ michael.mcmurtrey@inl.gov \\ messner@anl.gov \\ ssham@anl.gov \\ xuanzhang@anl.gov \\ wangh@ornl.gov \\ wangy3@ornl.gov \\ richard.wright@inl.gov
}

